\title{
Effects of combined application of chemical fertilizer and vermicompost on soil fertility, leaf yield and stevioside content of stevia
}

\author{
M. M. Zaman ${ }^{1}$, Md. Arifur Rahman ${ }^{2}$, Tanzin Chowdhury ${ }^{3}$ and M.A.H. Chowdhury ${ }^{2}$ \\ ${ }^{1}$ Soil Resources Development Institute, Farmgate, Dhaka, Bangladesh \\ ${ }^{2}$ Department of Agricultural Chemistry, Bangladesh Agricultural University, Mymensingh, Bangladesh \\ ${ }^{3}$ Department of Agricultural Chemistry, SAU, Sher-E-Bangla Nagar, Dhaka-1207, Bangladesh
}

\begin{tabular}{|c|c|}
\hline ARTICLE INFO & Abstract \\
\hline $\begin{array}{l}\text { Article history: } \\
\text { Received: 04 March } 2018 \\
\text { Accepted: 05 April } 2018\end{array}$ & \multirow{3}{*}{$\begin{array}{l}\text { Sustainable nutrient management with the combination of organic and chemical fertilizer amendment } \\
\text { expects a key part in upgrading stevia yield without harming the environment and to build up the nutrient } \\
\text { balance with increasing soil fertility. A pot experiment was conducted in the net house of the Department } \\
\text { of Agricultural Chemistry, Bangladesh Agricultural University, Mymensingh to study the combined effect } \\
\text { of vermicompost (VC) and chemical fertilizer (CF) on the growth, leaf biomass yield and stevioside } \\
\text { content of stevia in acid soil. Six combinations of VC and CF were applied following completely } \\
\text { randomized design (CRD) with three replications. Results showed that VC along with different rates of } \\
\mathrm{CF} \text { exerted significant influence on the growth, leaf biomass yield and stevioside content of stevia and } \\
\text { postharvest soil fertility. The highest values for most of the parameters were found from the plant } \\
\text { receiving VC @ } 7.5 \mathrm{t} \mathrm{ha}^{-1} \text { along with } 50 \% \mathrm{CF} \text {. About } 578 \% \text { higher leaf biomass yield was obtained from } \\
\text { the treatment } \mathrm{VC} \mathrm{C}_{7.5}+\mathrm{CF}_{50} \text { over control. Stevioside content was increased with the increasing levels of VC } \\
\text { up to } 7.5 \mathrm{tha} \mathrm{V}^{-1} \text { along with } 75 \% \text { of } \mathrm{CF} \text { and also with the advancement of growth period from } 30 \text { to } 60 \text { days } \\
\text { after planting. The highest amount of stevioside (11.05\%) was detected in the leaves of plant of the same } \\
\text { treatment at harvest. Soil acidity was significantly decreased with the increased levels of VC and CF } \\
\text { where as soil fertility in terms of organic matter and nutrient content was increased. Considering the } \\
\text { overall performance, farmers may be advised to cultivate stevia in acid soil applying VC @ } 7.5 \mathrm{t} \text { ha } \\
\text { along with } 50 \% \text { chemical fertilizer to boost up stevia production under the agroclimatic condition of the } \\
\text { study area in the context of Bangladesh. }\end{array}$} \\
\hline $\begin{array}{l}\text { Keywords: } \\
\text { Stevia, vermicompost, chemical } \\
\text { ertilizer, leaf yield, stevioside } \\
\text { content, acid soil }\end{array}$ & \\
\hline $\begin{array}{l}\text { Correspondence: } \\
\text { Md. Arifur Rahman } \\
\text { arif.bau11@gmail.com) }\end{array}$ & \\
\hline
\end{tabular}

\section{Introduction}

In the most recent years the rising concern about the spread of obesity and diabetes; a developing awareness about sound nourishments needs to be established. A strong enthusiasm toward stevia sweeteners, as an option of healthy nutrition and source of zero caloric sucrose, is increasing day by day. Stevia (Stevia rebaudiana Bertoni) is an essential characteristic endemic sweet herb containing sweetening compounds viz., stevioside, rebaudieside- $A$, rebaudieside- $B$ and $C$ and other compounds which assumes significant part to adjust insulin focus in individuals (Farooqi and Sreeramu, 2001). With the present interest for sustenance supplements having low carbohydrate, least calorie and low sugar content, the stevia plant and its extracts have turned out to be a definitive decision to fight against corpulence, cavities, hypertension, weakness, wretchedness, and furthermore against fungal disease (Dushyant et al., 2014). The sweetener derived from stevia is over to 300 times sweeter than sucrose (Liu et al., 2011; Ramya et al., 2014). Furthermore, the leaf concentrate of stevia has been accounted for elevated amounts of cancer prevention agent and antimicrobial movement (Singh et al., 2012; Taleie et al., 2012; Ramya et al,. 2014). Beside, stevioside has characteristics similar to saccharose, but has no effect on blood sugar, so it is of large industrial and therapeutic value and helpful for diabetes (Andolfi et al., 2006; Earanna, 2007; Dushyant et al., 2014; Ramya et al., 2014).

With the improvement and perfection of market economy, the indiscriminate application of chemical fertilizers increases which decreases soil fertility and nutrient quality of crops. This situation is created by losing of soil organic matter, which is the primary attributes of the sustainable cultivating frameworks (Liu et al., 2009). The use of inorganic fertilizer to maintain cropping was found to increase yield just for exactly couple of years, however, on a long run, it has not be effective and prompts soil degradation (Satyanarayana et al., 2002). The combined use of vermicompost and chemical fertilizers help in keeping up yield stability through correction of minimal lacks of auxiliary and micronutrients, improving effectiveness of connected supplements and providing favorable soil physical conditions (Gill and Walia, 2014). Vermicomposts are natural materials separated by collaborations between smaller microorganism and earthworms to produce completely balanced out natural soil amendments with low C:N proportions (Ramasamy et al., 2011). Earthworms enhance soil fertility and raise crop productivity by excreting beneficial soil organisms and secreting polysaccharides, proteins and different 
nitrogenous compound into the dirt (Hatti et al., 2010; Rekha et al., 2013). Vermicompost also contains some plant growth hormones and humic acids which improve the growth and yield of plant crops (Atiyeh et al., 2002). Singh and Wasnik (2013) studied the combined effect of vermicompost and chemical fertilizer on rosemary (Rosmarinus officinalis L) and found that application of vermicompost $\left(8 \mathrm{t} \mathrm{ha}^{-1}\right)$ along with fertilizer N-P-K fertilizer $\left(150-25-25 \mathrm{~kg} \mathrm{ha}^{-1}\right)$ produced optimum herbage and oil yield of rosemary compared with control (no fertilizer). Addition of $\mathrm{VC}$ and $\mathrm{CF}$ to the crop field could be a very good option considering the nutrient availability for maintaining soil fertility and productivity.

To the best of our knowledge, no published report is found on the integrated effects of vermicompost and chemical fertilizer on stevia cultivation in Bangladesh. BSRI and brac conducted some preliminary experiments on morphological and physiological parameters of stevia. Recently, some studies have been conducted and reported on suitable soils (Zaman et al., 2015a), N and S requirement and critical $\mathrm{N}$ and $\mathrm{S}$ content (Zaman et al., 2016ab), P use efficiency and critical P content; K requirement and $\mathrm{K}$ nutrition (Zaman et al., 2017ab) vermicompost and cow dung as organic manure (Zaman et al., 2015b; Zaman et al., 2017c) and poultry manure (Zaman et al., 2017d) in stevia grown in both acid and non-calcareous soils. Integrated effects of poultry manure and chemical fertilizer on the growth, leaf yield and stevioside content of stevia was also investigated by Zaman et al. (2015c). To the best of our insight, till now no detail study has yet been conducted about the combined effect of $\mathrm{VC}$ and $\mathrm{CF}$ in stevia cultivation. Hence, there is urgent need of research to establish optimal dose of vermicompost combined with chemical fertilizer to achieve higher growth, yield and quality improvement of stevia in a sustainable manner. Therefore, the predominant objective of the present study was to verify the integrated effects of different levels of vermicompost and chemical fertilizer on the growth, leaf biomass yield and stevioside content of stevia as well as post harvest soil fertility.

\section{Materials and Methods}

A pot experiment with Stevia rebaudiana (Bertoni) was carried out by combined application of vermicompost (VC) and chemical fertilizer (CF) on the growth, leaf biomass yield, stevioside content of stevia and postharvest soil fertility in response to their treatments. The experiment was conducted at the net house of the Department of Agricultural Chemistry, Bangladesh Agricultural University, Mymensingh, during February to May, 2013. Only acid soil was considered for this experiment. Approximately $40 \mathrm{~kg}$ acid soils were collected from $0-15 \mathrm{~cm}$ depth of selected fallow land of Madhupur under Tangail district of Bangladesh. The physico-chemical properties of initial soil and nutrient status of vermicompost have been presented in Table 1 .
Table 1. Physico-chemical properties of initial soil and nutrient status of vermicompost

\begin{tabular}{|c|c|c|}
\hline Parameters & $\begin{array}{l}\text { Physico-chemical } \\
\text { properties of } \\
\text { initial soil }\end{array}$ & $\begin{array}{l}\text { Nutrient status } \\
\text { of } \\
\text { vermicompost }\end{array}$ \\
\hline $\mathrm{pH}$ & 5.1 & 6.9 \\
\hline $\begin{array}{l}\text { Electrical conductivity } \\
\left(\mathrm{dS} \mathrm{m} \mathrm{m}^{-1}\right)\end{array}$ & 0.25 & - \\
\hline Particle density $\left(\mathrm{g} \mathrm{cc}^{-1}\right)$ & 1.25 & - \\
\hline Bulk density ( $\left.\mathrm{g} \mathrm{cc}^{-1}\right)$ & 2.23 & - \\
\hline Field capacity $(\%)$ & 29.88 & \\
\hline Organic C (\%) & 1.56 & 8.93 \\
\hline Total N (\%) & 0.09 & 1.35 \\
\hline Available P (\%) & 0.0003 & 0.81 \\
\hline Available S (\%) & 0.0018 & 0.28 \\
\hline $\begin{array}{l}\text { Exchangeable } \mathrm{K} \\
\left(\mathrm{cmol} \mathrm{kg}^{-1}\right)\end{array}$ & 0.19 & 0.62 \\
\hline
\end{tabular}

After proper cleaning, the soil was sieved through a 2 $\mathrm{mm}$ sieve and $500 \mathrm{~g}$ sieved soil from each source was preserved for chemical analysis. The physicochemical analysis of processed soil, vermicompost and postharvest soil was performed in different laboratories of the Department of Agricultural Chemistry, Biochemistry, Professor Muhammed Hussain Central Laboratory (PMHCL), BAU, Mymensingh and SRDI Regional Laboratory, Dhaka as reported by Page et al. (1982). All the chemicals used were analytical reagent (AR) grade. Stevia seedling was raised in broad earthen pots $(30 \mathrm{~cm} \times 23 \mathrm{~cm})$ containing $8 \mathrm{~kg}$ processed soil per pot. Plant samples were procured from brac Biotechnology Laboratory, Joydebpur, Gazipur. As basal doses, N, P, K, S, Zn and B fertilizers were applied as rates of 250,100, 200, 30, 3 and $1 \mathrm{~kg} \mathrm{ha}^{-1}$ from TSP, MoP, gypsum, zinc sulphate and boric acid, respectively. Sulphur rate was adjusted from both gypsum and zinc sulphate. Six experimental treatments viz., $\mathrm{VC}_{0}+\mathrm{CF}_{0}$ (No fertilizer), $\mathrm{VC}_{0}+\mathrm{CF}_{100}$ (VC @ $0 \mathrm{t} \mathrm{ha}^{-1}$ plus $100 \%$ $\mathrm{CF}), \mathrm{VC}_{5}+\mathrm{CF}_{50}\left(\mathrm{VC} @ 5 \mathrm{t} \mathrm{ha}^{-1}\right.$ plus 50\% CF), $\mathrm{VC}_{5}+\mathrm{CF}_{75}$ (VC@ $5 \mathrm{t} \mathrm{ha}^{-1}$ plus 75\% CF), $\mathrm{VC}_{7.5}+\mathrm{CF}_{50}$ (VC@ $7.5 \mathrm{t} \mathrm{ha}^{-1}$ plus 50\% CF), $\mathrm{VC}_{7.5}+\mathrm{CF}_{75}$ (VC@ $7.5 \mathrm{t}$ $\mathrm{ha}^{-1}$ plus $75 \% \mathrm{CF}$ ) were used. The experiment was laid out in completely randomized design (CRD) with three replications using total 18 earthen pots. Intercultural operations were done as and when necessary. Data were collected at 15, 30, 45 and 60 days after planting (DAP) and was harvested at $60 \mathrm{DAP}$. After harvesting the crop, leaf samples were processed and dried at $60^{\circ} \mathrm{C}$ for 72 hours, weighed, ground and stored. Different growth parameters like plant height, branches plant ${ }^{-1}$, leaves plant $^{-1}$, leaf area plant ${ }^{-1}$, fresh and dry leaf weight ( $g$ plant $^{-1}$ ) of stevia were studied. Stevioside content of stevia leaf was determined following the standard method (Kolb et al., 2001). The concentrations of N, P, $\mathrm{K}$ and $\mathrm{S}$ in stevia were analyzed by standard methods (Tandon, 1995). Nutrient uptake was calculated from their concentrations and corresponding dry leaf yield. The obtained results were subjected to statistical analysis 
using standard method of analysis described by Steel et al. (1997). Analysis of variance (ANOVA) was done following the principle of F-statistics and the mean values were separated by Latin Square Design (LSD) (Gomez and Gomez, 1984).

\section{Results and Discussion}

Application of different rates of vermicompost and chemical fertilizer in stevia significantly $(\mathrm{P}<0.05)$ affected the growth, leaf biomass yield and stevioside content of stevia during the study period of 60 days.

\section{Plant height}

Significant increase was observed among different combinations of $\mathrm{VC}$ and $\mathrm{CF}$ in recording plant height of stevia during different growth intervals (Fig. 1). The results revealed that plant height of stevia was gradually increased with time of growth period.

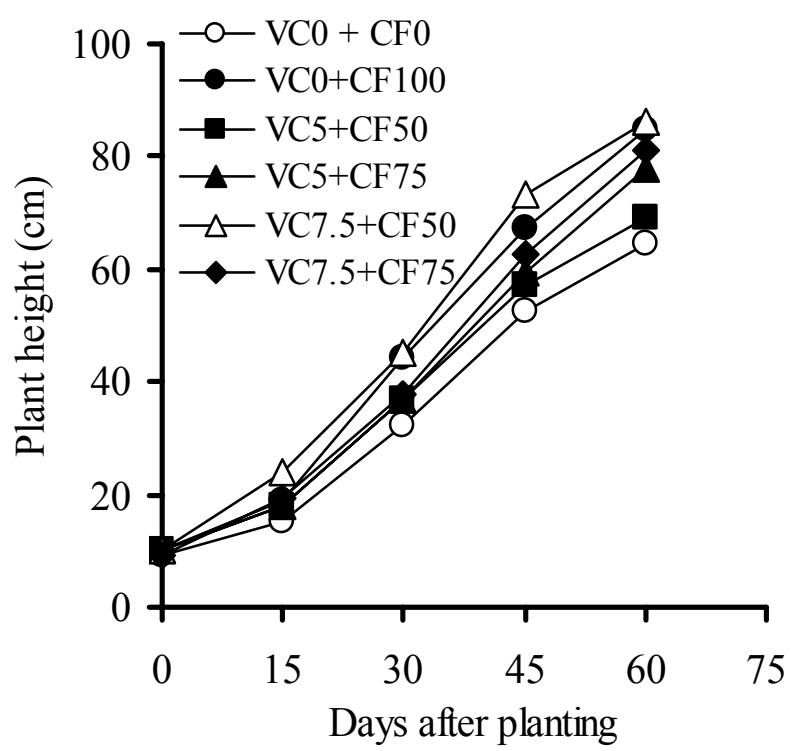

Fig. 1. Integrated effects of vermicompost and chemical fertilizer on plant height of stevia

At harvest, the tallest plant $(86 \mathrm{~cm})$ was recorded from the integrated application of $\mathrm{VC}\left(7.5 \mathrm{t} \mathrm{ha}^{-1}\right)$ and $\mathrm{CF}$ $(50 \%)$. The second highest plant height was observed from $\mathrm{VC}_{7.5}+\mathrm{CF}_{75}$ treatment which was identical with the treatment giving the tallest plant. The shortest plant $(64.67 \mathrm{~cm})$ was noticed in control treatment. Our results agreed with those obtained by Parthasarathi et al. (2008) who found that supplementation of $\mathrm{N}, \mathrm{P}$ and $\mathrm{K}$ with vermicompost enhanced the growth and yield of black gram (Vigna mungo). The increased plant height through the use of composts along with $\mathrm{N}, \mathrm{P}$ and $\mathrm{K}$ was also reported by Kobayashi et al. (1989). Our result was also in line of the work of Dushyant et al. (2014), who found that the application of vermicompost combined with bone meal at 75:25 ratio showed the highest plant height. Zaman et al. (2015c) found the tallest plant (83 $\mathrm{cm}$ ) by applying poultry manure (PM) @ $3 \mathrm{t} \mathrm{ha}^{-1}$ along with $75 \% \mathrm{CF}$. In this study, the combined use of $\mathrm{VC}$ and $\mathrm{CF}$ gave the better plant height of stevia than that of found through the amendment of cow dung and PM alone (Zaman et al., 2017cd).

\section{Branch number}

The number of branches plant ${ }^{-1}$ was varied significantly due to the different combined applications of $\mathrm{VC}$ and $\mathrm{CF}$ at various days after planting (DAP) (Fig. 2). Branch numbers increased slowly up to 15 DAP and then increased rapidly up to $60 \mathrm{DAP}$. At harvest, the highest number of branches plant ${ }^{-1}$ (11.3) was observed in the plant treated with VC@ $7.5 \mathrm{t} \mathrm{ha}^{-1}$ in combination with $50 \%$ CF where as the lowest branch number was observed throughout the growth period in the control treatment. The second highest number of branches (10.33) was counted from $\mathrm{VC}_{5.0}+\mathrm{CF}_{50}$. This might be because of use of good natural source i.e. vermicompost which enables great air movement of soil moisture and environmental elements.

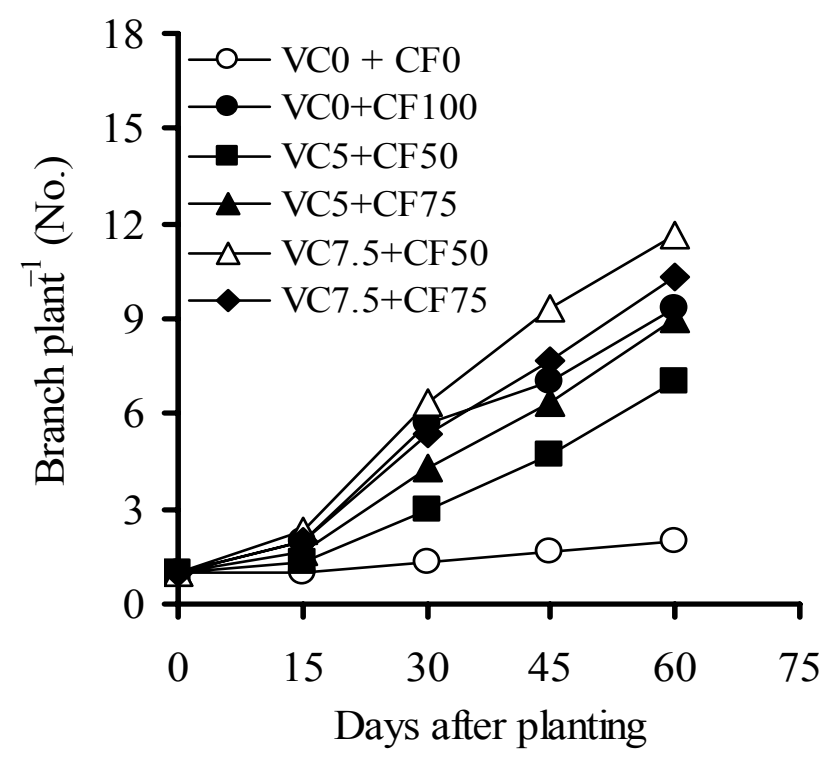

Fig. 2. Integrated effects of vermicompost and chemical fertilizer on branch number of stevia

The obtained result was better than that of finding observed by Zaman et al. (2015c) applying VC alone. Dushyant et al. (2014) was also reported that the stevia plants under treatment (vermicompost : bone meal = 75:25) had the maximum number of branches. Similar trend was also found by Khatik and Dikshit (2001).

\section{Leaf number}

The number of leaves plant ${ }^{-1}$ expanded gradually in before days because of foundation and after that the sudden development in number of leaves was taken note. The number of leaves from 15 to 60 DAP ranged from 18.0 to 257.0 with the treatment of $\mathrm{VC}_{5}+\mathrm{CF}_{50}$ and 19.3 to 314.0 in $\mathrm{VC}_{7.5}+\mathrm{CF}_{75}$. Leaf number differed significantly due to the application of different levels of VC and CF at various DAP (Fig. 3). A rapid and tremendous increase in leaf number was observed in the plant fertilized with VC@ $9.5 \mathrm{t} \mathrm{ha}^{-1}$ along with 50\% CF. Among the experimental treatments; $\mathrm{VC}_{7.5}+\mathrm{CF}_{50}$ had the 
maximum number of leaf per plant (314.0), which was significantly different from other combinations. In contrast, the lowest leaf number was observed in the plant receiving neither $\mathrm{VC}$ nor $\mathrm{CF}$ at harvest. The results revealed that the combined application of $\mathrm{VC}$ and $\mathrm{CF}$ gave greater amount of leaves per plant than the sole application of VC as reported by Zaman et al. (2015b). At harvest, leaf number was increased by $287-577 \%$ over control irrespective of treatments. On the contrary, the research with application of integrated PM and CF found $179-302 \%$ increase of leaf number of stevia at harvest (Zaman et al., 2015c).

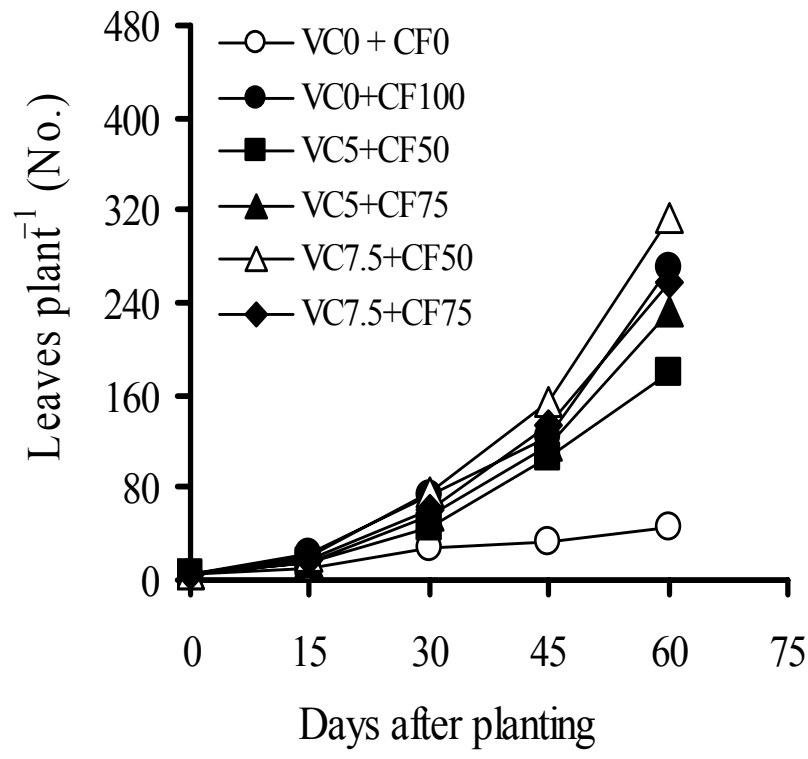

Fig. 3. Integrated effects of vermicompost and chemical fertilizer on leaf number of stevia

\section{Leaf area}

The highest leaf area plant ${ }^{-1}\left(2356 \mathrm{~cm}^{2}\right)$ was measured from the application of $\mathrm{VC}_{7.5}+\mathrm{CF}_{50}$ which was identical with $\mathrm{VC}_{7.5}+\mathrm{CF}_{75}$ and $\mathrm{VC}_{0}+\mathrm{CF}_{100}$ at harvest but significantly different from others (Table 2). The lowest leaf area plant ${ }^{-1}\left(142 \mathrm{~cm}^{2}\right)$ was noticed in the plant grown in control treatment $\left(\mathrm{VC}_{0}+\mathrm{CF}_{0}\right)$. At harvest, application of the highest rate of $\mathrm{VC}\left(7.5 \mathrm{t} \mathrm{ha}^{-1}\right)$ and $\mathrm{CF}$ $(50 \%)$ showed an increase of 16 folds of leave area per plant as compared to control. In this study, leaf area was greater than that of finding reported by Zaman et al. (2015b), which was $1126 \mathrm{~cm}^{2}$ in acid soil from the treatment $7.5 \mathrm{t} \mathrm{VC} \mathrm{ha}^{-1}$ alone. Zaman et al. (2015c) found the highest leaf area plant ${ }^{-1}\left(2307 \mathrm{~cm}^{2}\right.$ in acid soil $)$ of stevia fertilized with PM @ $3 \mathrm{t} \mathrm{ha}^{-1}$ along with 75\% CF. Singh et al. (2010) reported that some morphological attributes such as plant height and leaf area was improved by application of vermicompost leachate in strawberry. Ayyobi et al. (2013) reported that differences between peppermint plants treated with organic fertilizer was not significant for leaf area index and shoot dry weight. Maheshwar (2005) and Khanom et al. (2008) observed the enhanced leaf parameters with increased levels of fertilizers. Vermicompost contained numerous humic acids, which enhances the number of leaf, leaf area index, plant height and increased the growth rate (Atarzadeh et al., 2013).

Table 2. Integrated effects of vermicompost and chemical fertilizer on leaf area, dry weight and yield increase of stevia leaves over control at harvest

\begin{tabular}{cccc}
\hline $\begin{array}{c}\text { Experimental } \\
\text { treatment }\end{array}$ & $\begin{array}{c}\text { Leaf area } \\
\text { plant } \\
\left(\mathrm{cm}^{2}\right)\end{array}$ & $\begin{array}{c}\text { Leaf dry } \\
\text { weight } \\
\left(\text { g plant }^{-1}\right)\end{array}$ & $\begin{array}{c}\text { Yield increase } \\
\text { over } \\
\text { Control }(\%)\end{array}$ \\
\hline $\mathrm{VC}_{0}+\mathrm{CF}_{0}$ & $142 \mathrm{c}$ & $1.40 \mathrm{~d}$ & - \\
$\mathrm{VC}_{0}+\mathrm{CF}_{100}$ & $1930 \mathrm{ab}$ & $8.16 \mathrm{~b}$ & 482.8 \\
$\mathrm{VC}_{5}+\mathrm{CF}_{50}$ & $1604 \mathrm{~b}$ & $5.40 \mathrm{c}$ & 285.7 \\
$\mathrm{VC}_{5}+\mathrm{CF}_{75}$ & $1688 \mathrm{~b}$ & $7.02 \mathrm{~b}$ & 401.4 \\
$\mathrm{VC}_{7.5}+\mathrm{CF}_{50}$ & $2356 \mathrm{a}$ & $9.50 \mathrm{a}$ & 578.6 \\
$\mathrm{VC}_{7.5}+\mathrm{CF}_{75}$ & $1987 \mathrm{ab}$ & $7.77 \mathrm{~b}$ & 455.0 \\
$\mathrm{CV}(\%)$ & 3.94 & 3.31 & - \\
$\mathrm{LSD}_{0.05}$ & 328 & 0.64 & - \\
\hline
\end{tabular}

$\mathrm{VC}=$ Vermicompost $\mathrm{CF}=$ Chemical fertilizer; $\mathrm{CV}=$ Coefficient of variance and LSD = Least significant difference

\section{Fresh weight}

The results showed that the amount of fresh biomass yield of stevia has been found to increase progressively irrespective of treatments over control (Fig. 4). However the magnitude of such changes varied with treatments, being recorded highest fresh weight plant $^{-1}$ (35.24 g) at harvest in the treatment $\mathrm{VC}_{7.5}+\mathrm{CF}_{75}$ which might be due to combined application of $\mathrm{VC}$ and $\mathrm{CF}$. The significant increase in fresh weight of leaves plant ${ }^{-1}$ at harvest was found up to the rate of $\mathrm{VC}\left(7.5 \mathrm{t} \mathrm{ha}^{-1}\right)$ and $\mathrm{CF}$ (75\%) resulted an increase by 7 folds as compared to control (Fig. 4).

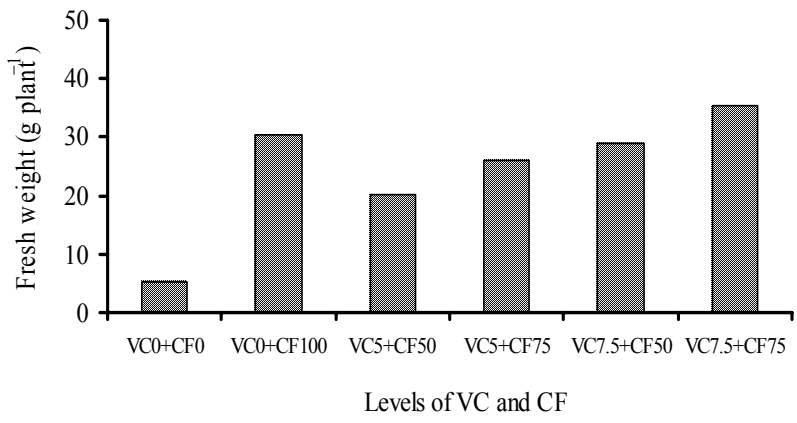

Fig. 4. Integrated effects of vermicompost and chemical fertilizer on fresh weight of stevia leaves

Fallah et al. (2006) carried out an experiment and concluded that the application of VC significantly increased the fresh weight of stevia leaves. Azarpour et al. (2013) obtained the highest fresh leaf biomass yield of stevia from the treatment where $10 \mathrm{t} \mathrm{ha}^{-1}$ vermicompost were applied. Patil (2010) also found similar trends as total fresh biomass production was the highest with combined application of biofertilizer when compared to the sole application. 


\section{Dry weight}

Rate of $\mathrm{VC}$ and $\mathrm{CF}$ application has resulted in significant increase in leaf dry weight of stevia and the highest dry biomass $\left(9.50 \mathrm{~g} \mathrm{plant}^{-1}\right)$ was found from the combination of VC $\left(7.5 \mathrm{t} \mathrm{ha}^{-1}\right)$ and $\mathrm{CF}(50 \%)$ treatments as compared to control (Table 2). Results revealed that dry weight progressively increased with increasing levels of $\mathrm{VC}$ and $\mathrm{CF}$ application up to $\mathrm{VC}_{7.5}+\mathrm{CF}_{50}$ and then declined with further addition $\left(\mathrm{VC}_{7.5}+\mathrm{CF}_{75}\right)$. Second highest value $(8.16 \mathrm{~g})$ was obtained from $\mathrm{VC}_{0}+\mathrm{CF}_{100}$. The lowest value was obtained from the control treatment $\left(\mathrm{VC}_{0}+\mathrm{CF}_{0}\right)$. The leaf dry yield was $578 \%$ higher in respect of combined application of $\mathrm{VC}$ (a) $7.5 \mathrm{t} \mathrm{ha}^{-1}$ and $50 \% \mathrm{CF}$ over control. Dry weight increased by 285 to $578 \%$ in over control across the treatments. Zaman et al. (2015b) found that VC application at all levels increased leaf dry yield at harvest by 119 to $335 \%$ in acid soil. Dushyant et al. (2014) reported that combined application of vermicompost and bone meal showed the highest number of leaves as well as maximum fresh and dry weight of leaves in stevia. Our results corroborated with the findings of other investigators (Tomati et al., 1990; Bachman and Metzger, 2008; Joshi and Vig, 2010). They reported significant increase in growth parameters of plants after application of vermicompost in the growth media. Earthworms may stimulate microbial activities and metabolism and also influence microbial populations. Higher fresh leaf yield and dry leaf yield of stevia was noted with application of higher vermicompost and bone meal (75: 25 ratio), which had the maximum leaf yield (Dushyant et al., 2014). As a consequence, more available nutrients and microbial metabolites are released into the soil (Tomati et al., 1998). This result was also in line with results of Liu et al. (2011) who used organic manure and inorganic fertilizers. Jeyabal and Kuppusamy (2001) recorded that the combined use of vermicompost along with $\mathrm{N}$ fertilizer and bio fertilizers (Azospirillum and Phosphobacteria) increased rice yield by $15.9 \%$ over application with $\mathrm{N}$-fertilizer alone.

\section{Leaf nutrient content and their uptake}

Data on the major mineral nutrients i.e. $\mathrm{N}, \mathrm{P}, \mathrm{K}$ and $\mathrm{S}$ contents and their uptake by stevia leaves as influenced by different combinations of $\mathrm{VC}$ and $\mathrm{CF}$ have been presented in Table 3. The leaf nutrient content was increased with increasing combinations of $\mathrm{VC}$ and $\mathrm{CF}$. The highest concentrations of nutrient (N, P, K and S as $1.60,0.30,1.88$ and $0.18 \%$, respectively) were obtained when VC was applied @ $7.5 \mathrm{t} \mathrm{ha}^{-1}$ combined with 75\% of CF. The lowest nutrient content of N, P, K and S was obtained from the plants receiving no $\mathrm{VC}$ and $\mathrm{CF}$. Nutrients uptake was also significantly affected by the application of $\mathrm{VC}$ and $\mathrm{CF}$. The uptake did not follow the same trend like concentrations of leaf nutrients. The highest uptake was found from $\mathrm{VC}_{7.5}+\mathrm{CF}_{50}$ for all the nutrients which varied from 15.82 to $142.53,1.54$ to $23.75,14.28$ to 170.03 and 0.84 to $14.20 \mathrm{mg} \mathrm{pot}^{-1}$ for $\mathrm{N}$, $\mathrm{P}, \mathrm{K}$ and $\mathrm{S}$, respectively (Table 3). The uptake of nutrients increased up to $\mathrm{VC}_{7.5}+\mathrm{CF}_{50}$ and then decreased with further additions $\left(\mathrm{VC}_{7.5}+\mathrm{CF}_{75}\right)$.

Table 3. Integrated effects of different levels of vermicompost and chemical fertilizer on contents and uptake of $\mathbf{N}, \mathbf{P}, \mathrm{K}$ and $\mathrm{S}$ by stevia at harvest

\begin{tabular}{ccccccccc}
\hline \multirow{2}{*}{$\begin{array}{c}\text { Experimental } \\
\text { treatment }\end{array}$} & \multicolumn{2}{c}{ Nitrogen $(\mathrm{N})$} & \multicolumn{2}{c}{ Phosphorus $(\mathrm{P})$} & \multicolumn{2}{c}{ Potassium $(\mathrm{K})$} & \multicolumn{2}{c}{ Sulphur (S) } \\
\cline { 2 - 8 } & $\begin{array}{c}\text { Content } \\
(\%)\end{array}$ & $\begin{array}{c}\text { Uptake } \\
\left(\mathrm{mg} \mathrm{pot}^{-1}\right)\end{array}$ & $\begin{array}{c}\text { Content } \\
(\%)\end{array}$ & $\begin{array}{c}\text { Uptake } \\
\left(\mathrm{mg} \mathrm{pot}^{-1}\right)\end{array}$ & $\begin{array}{c}\text { Content } \\
(\%)\end{array}$ & $\begin{array}{c}\text { Uptake } \\
\left(\mathrm{mg} \mathrm{pot}^{-1}\right)\end{array}$ & $\begin{array}{c}\text { Content } \\
(\%)\end{array}$ & $\begin{array}{c}\text { Uptake } \\
\left(\mathrm{mg} \mathrm{pot}^{-1}\right)\end{array}$ \\
\hline $\mathrm{VC}_{0}+\mathrm{CF}_{0}$ & $1.12 \mathrm{c}$ & $15.82 \mathrm{e}$ & $0.11 \mathrm{c}$ & $1.54 \mathrm{c}$ & $1.02 \mathrm{~d}$ & $14.28 \mathrm{e}$ & $0.06 \mathrm{~b}$ & $0.84 \mathrm{c}$ \\
$\mathrm{VC}_{0}+\mathrm{CF}_{100}$ & $1.37 \mathrm{abc}$ & $107.71 \mathrm{c}$ & $0.23 \mathrm{ab}$ & $18.71 \mathrm{a}$ & $1.72 \mathrm{~b}$ & $140.21 \mathrm{~b}$ & $0.12 \mathrm{ab}$ & $9.80 \mathrm{ab}$ \\
$\mathrm{VC}_{5}+\mathrm{CF}_{50}$ & $1.25 \mathrm{bc}$ & $67.40 \mathrm{~d}$ & $0.18 \mathrm{~b}$ & $9.77 \mathrm{bc}$ & $1.45 \mathrm{c}$ & $78.41 \mathrm{~d}$ & $0.11 \mathrm{ab}$ & $5.41 \mathrm{bc}$ \\
$\mathrm{VC}_{5}+\mathrm{CF}_{75}$ & $1.38 \mathrm{ab}$ & $98.24 \mathrm{c}$ & $0.24 \mathrm{ab}$ & $16.15 \mathrm{ab}$ & $1.74 \mathrm{~b}$ & $122.38 \mathrm{c}$ & $0.14 \mathrm{a}$ & $9.83 \mathrm{ab}$ \\
$\mathrm{VC}_{7.5}+\mathrm{CF}_{50}$ & $1.57 \mathrm{ab}$ & $142.53 \mathrm{a}$ & $0.25 \mathrm{a}$ & $23.75 \mathrm{a}$ & $1.79 \mathrm{~b}$ & $170.03 \mathrm{a}$ & $0.15 \mathrm{a}$ & $14.20 \mathrm{a}$ \\
$\mathrm{VC}_{7.5}+\mathrm{CF}_{75}$ & $1.64 \mathrm{a}$ & $123.13 \mathrm{~b}$ & $0.30 \mathrm{a}$ & $22.32 \mathrm{a}$ & $1.88 \mathrm{a}$ & $146.15 \mathrm{~b}$ & $0.18 \mathrm{a}$ & $13.99 \mathrm{a}$ \\
$\mathrm{CV}(\%)$ & 8.54 & 4.75 & 13.73 & 21.85 & 3.88 & 3.22 & 19.33 & 21.42 \\
$\mathrm{LSD}_{0.05}$ & 0.20 & 6.58 & 0.13 & 2.01 & 018 & 5.30 & 0.07 & 0.36 \\
\hline
\end{tabular}

$\mathrm{VC}=$ Vermicompost $\mathrm{CF}=$ Chemical fertilizer; $\mathrm{CV}=$ Coefficient of variance and $\mathrm{LSD}=$ Least significant difference

The highest $\mathrm{N}$ uptake was recorded by the application of VC@ $7.5 \mathrm{t} \mathrm{ha}^{-1}+50 \% \mathrm{CF}$ over the control but remained at par with other treatments. A similar trend was observed with respect to $\mathrm{P}$ and $\mathrm{K}$ uptake by stevia. It has been observed that the magnitude of $\mathrm{N}$ and $\mathrm{K}$ uptake was greater than $\mathrm{P}$ and $\mathrm{S}$. Enhanced concentration of $\mathrm{P}$ in stevia by the vermicompost might be due to the increase in solubilization of $\mathrm{P}$ either by microorganism activation with excretion of organic acids such as citric, glutamic, tartaric, succinic, lactic, oxalic, malic, and fumaric or by greater phosphatase activity.
The increase in nutrient content was proportional with the rate of application but the nutrient uptake did not follow the same trend. Higher nutrient uptake might be related to higher biomass yield. This may be due to the highest dry leaf yield harvested from that treatment. Because nutrient uptake was calculated from their concentrations and corresponding dry leaf yield. The activity of night crawlers quickens organic matter mineralization, disintegration of polysaccharides, increment the humus in the soil, and oppositely diminished the accessibility of poisonous overwhelming components to plants (Dominguez et al., 1997). Jadhav et al. (2001) conducted a study to determine the effect of 
vermicompost and chemical fertilizers on the soil nutrient status of mulberry and found that higher soil available $\mathrm{N}$ content was observed in treatment receiving vermicompost $@, 5 \mathrm{t} \mathrm{ha}^{-1}$ alone and in combination with $100 \%$ RDF (Refuse-derived fuel). The greater uptake of NPK under different treatment combinations was due to the combined influence of greater nutrient concentrations and dry matter yield with these treatments (Kumar et al., 2013). Vasanthi and Kumarasamy (1996) found the highest micronutrients content in the treatment that received vermicompost along with NPK fertilizer compared to $\mathrm{N}$ alone.

\section{Stevioside content}

There was a significant effect of different levels of VC and CF on the stevioside content of stevia leaf (Table 4). Stevioside content of the leaf was gradually increased with increasing levels of $\mathrm{VC}$ and $\mathrm{CF}$.

Table 4. Integrated effects of vermicompost and chemical fertilizer on the stevioside content of stevia leaf at various DAP

\begin{tabular}{cccc}
\hline Experimental & \multicolumn{3}{c}{ Stevioside content (\%) } \\
\cline { 2 - 4 } treatment & $30 \mathrm{DAP}$ & $45 \mathrm{DAP}$ & $60 \mathrm{DAP}$ \\
\hline $\mathrm{VC}_{0}+\mathrm{CF}_{0}$ & $3.56 \mathrm{~d}$ & $4.32 \mathrm{e}$ & $5.82 \mathrm{e}$ \\
$\mathrm{VC}_{0}+\mathrm{CF}_{100}$ & $3.88 \mathrm{~d}$ & $5.05 \mathrm{~d}$ & $6.58 \mathrm{~d}$ \\
$\mathrm{VC}_{5}+\mathrm{CF}_{50}$ & $4.85 \mathrm{c}$ & $6.81 \mathrm{c}$ & $8.97 \mathrm{c}$ \\
$\mathrm{VC}_{5}+\mathrm{CF}_{75}$ & $5.53 \mathrm{c}$ & $7.79 \mathrm{~b}$ & $9.23 \mathrm{~b}$ \\
$\mathrm{VC}_{7.5}+\mathrm{CF}_{50}$ & $6.35 \mathrm{~b}$ & $8.96 \mathrm{~b}$ & $10.74 \mathrm{a}$ \\
$\mathrm{VC}_{7.5}+\mathrm{CF}_{75}$ & $7.84 \mathrm{a}$ & $9.85 \mathrm{a}$ & $11.05 \mathrm{a}$ \\
$\mathrm{CV}(\%)$ & 2.25 & 2.26 & 2.05 \\
$\mathrm{LSD}_{0.05}$ & 0.61 & 0.47 & 0.80 \\
\hline
\end{tabular}

$\mathrm{VC}=$ Vermicompost $\mathrm{CF}=$ Chemical fertilizer; DAP $=$ Days after planting, $\mathrm{CV}=$ Coefficient of variance and $\mathrm{LSD}=$ Least significant difference.

The highest stevioside content $(11.05 \%)$ was found in the leaves of stevia fertilized with VC@7.5 $\mathrm{t} \mathrm{ha}^{-1}$ along with $75 \% \mathrm{CF}$, which was identical with $\mathrm{VC}_{7.5}+\mathrm{CF}_{50}$ at harvest. but significantly different with other treatments irrespective of growth period. Stevioside contents were also significantly increased with the advancement of growth period from 30 to 60 DAP irrespective of treatments. The outcomes were as per the findings of Das and Dang (2010), who found the expanded stevioside content with advanced growth period and most astounding content of stevioside in the stevia leaf of the biomanure treated plant. This might be found due to expanded measure of natural carbon and other macro and micronutrient substances in the acid soil with application of VC and CF (Das and Dang, 2010). The lowest stevioside content was obtained from the plant fertilized with neither VC nor CF. The outcomes additionally imagined that the content of stevioside has been recorded most elevated in the consolidated use of $\mathrm{VC}$ and $\mathrm{CF}$ over that of relating sole application of $\mathrm{CF}$ and that of control treatment. Zaman et al. (2015c) found the highest stevioside content $(10.45 \%)$ in acid soil fertilized with PM@5 t ha ${ }^{-1}$ combined with 75\% CF. Patil (2010) obtained the highest content of carbohydrate of stevia plants with the combination of NPK (inorganic fertilizer) and vermicompost. The stevioside was accumulated in the leaves all through the development time of the stevia and concentrated especially at the later growth stage might be because of higher leaf territory and high net photosynthetic rate (Zaman et al., 2015c).

\section{Postharvest soil fertility status}

In terms of soil fertility and plant growth, vermicompost assumed a vital part in enhancing soil texture, aeration, soil compaction and in this way improves more water and nutrients take-up by plants from their encompassing regions of root zone (Kashem et al., 2015). Soil pH and available nutrient of soil were significantly affected by different levels of $\mathrm{VC}+\mathrm{CF}$ combination after the harvest of the crop. The changes observed in the physicochemical properties of postharvest soil altered by different treatments (Table 5a \& 5b). The data revealed that all the parameters were significantly influenced by the addition of $\mathrm{VC}$ and $\mathrm{CF}$.

Table 5a. Integrated effects of vermicompost and
chemical fertilizer on pH, OM
nutrient status of postharvest soil
and

$\mathrm{VC}=$ Vermicompost $\mathrm{CF}=$ Chemical fertilizer, $\mathrm{CV}=$ Coefficient of variance, $\mathrm{LSD}=$ Least significant difference and Exch. $=$ Exchangeable

Table 5b. Integrated effects of vermicompost and chemical fertilizer on $\mathrm{pH}, \mathrm{OM}$ and nutrient status of postharvest soil

\begin{tabular}{cccccc}
\hline $\begin{array}{c}\text { Experimental } \\
\text { treatment }\end{array}$ & $\begin{array}{c}\text { Available } \\
\left(\mu \mathrm{g} \mathrm{g}^{-1}\right)\end{array}$ & $\begin{array}{c}\text { Exch. } \\
\mathrm{Ca} \\
\left(\mathrm{cmol} \mathrm{kg}^{-1}\right)\end{array}$ & $\begin{array}{c}\text { Exch. } \\
\mathrm{Mg} \\
\left(\mathrm{cmol} \mathrm{kg}^{-1}\right)\end{array}$ & $\begin{array}{c}\text { Available } \\
\mathrm{Zn} \\
\left(\mu \mathrm{g} \mathrm{g}^{-1}\right)\end{array}$ & $\begin{array}{c}\text { Available } \\
\left(\mu \mathrm{g} \mathrm{g}^{-1}\right)\end{array}$ \\
\hline $\mathrm{VC}_{0}+\mathrm{CF}_{0}$ & $11.88 \mathrm{~d}$ & $0.12 \mathrm{c}$ & $0.51 \mathrm{c}$ & $1.13 \mathrm{c}$ & $0.29 \mathrm{~d}$ \\
$\mathrm{VC}_{0}+\mathrm{CF}_{100}$ & $17.11 \mathrm{~d}$ & $1.98 \mathrm{~b}$ & $0.94 \mathrm{a}$ & $1.87 \mathrm{~b}$ & $0.64 \mathrm{c}$ \\
$\mathrm{VC}_{5}+\mathrm{CF}_{50}$ & $16.56 \mathrm{c}$ & $1.83 \mathrm{a}$ & $0.89 \mathrm{a}$ & $1.80 \mathrm{ab}$ & $0.53 \mathrm{~b}$ \\
$\mathrm{VC}_{5}+\mathrm{CF}_{75}$ & $21.08 \mathrm{~b}$ & $2.32 \mathrm{a}$ & $1.06 \mathrm{a}$ & $1.96 \mathrm{a}$ & $0.82 \mathrm{a}$ \\
$\mathrm{VC}_{7.5}+\mathrm{CF}_{50}$ & $22.90 \mathrm{a}$ & $2.66 \mathrm{a}$ & $1.24 \mathrm{a}$ & $2.10 \mathrm{a}$ & $0.89 \mathrm{a}$ \\
$\mathrm{VC}_{7.5}+\mathrm{CF}_{75}$ & $21.73 \mathrm{~b}$ & $2.13 \mathrm{a}$ & $1.22 \mathrm{a}$ & $2.09 \mathrm{a}$ & $0.87 \mathrm{a}$ \\
$\mathrm{CV}(\%)$ & 4.42 & 10.83 & 5.01 & 9.23 & 9.64 \\
$\mathrm{LSD}_{0.05}$ & 0.87 & 1.06 & 0.92 & 0.17 & 0.15 \\
\hline
\end{tabular}

$\mathrm{VC}=$ Vermicompost $\mathrm{CF}=$ Chemical fertilizer, $\mathrm{CV}=$ Coefficient of variance, $\operatorname{LSD}=$ Least significant difference and Exch.= Exchangeable.

The acidity of soil decreased with the combined application of $\mathrm{VC}$ and $\mathrm{CF}$ with increasing the soil $\mathrm{pH}$ up to 5.8. Sailaja Kumari and Usha Kumari (2000) indicated that the $\mathrm{pH}$ of the acid soil was increased due to vermicompost application. Soil organic carbon (OC) after harvest of stevia was significantly greater in the pots supplied with greater amount of $\mathrm{VC}$ and $\mathrm{CF}$ compared to control. Organic matter content increased over control as a range of 1.57 to $2.52 \%$. The contents of total $\mathrm{N}$, available $\mathrm{P}, \mathrm{S}, \mathrm{Zn}$ and $\mathrm{B}$, exchangeable $\mathrm{K}, \mathrm{Ca}$ and $\mathrm{Mg}$ were also significantly increased with the increased levels of treatments up to $\mathrm{VC}_{7.5}+\mathrm{CF}_{50}$. The highest values of the parameters were also obtained when vermicompost was applied@ $7.5 \mathrm{t} \mathrm{ha}^{-1}$ along with $50 \% \mathrm{CF}$ and the lowest values were from the control $\left(\mathrm{VC}_{0}\right)$. Significantly lower amount of different mineral elements in harvested soil was recorded in control as 
compared to the pots supplied with CF either alone or in combination with VC (Table 5a \& 5b). Zaman et al. (2015b) found that the highest values of the parameters in post-harvest soil were obtained when VC was applied (a) $10 \mathrm{t} \mathrm{ha}$. Vermicompost contained a higher concentration of exchangeable $\mathrm{K}$ due to enhanced microbial activity during the vermicomposting process, which consequently enhanced the rate of mineralization (Manivannan et al., 2009). They also found that increased growth of the beans (Phaseolus vulgaris) were

\section{$\%$ Increase over control}
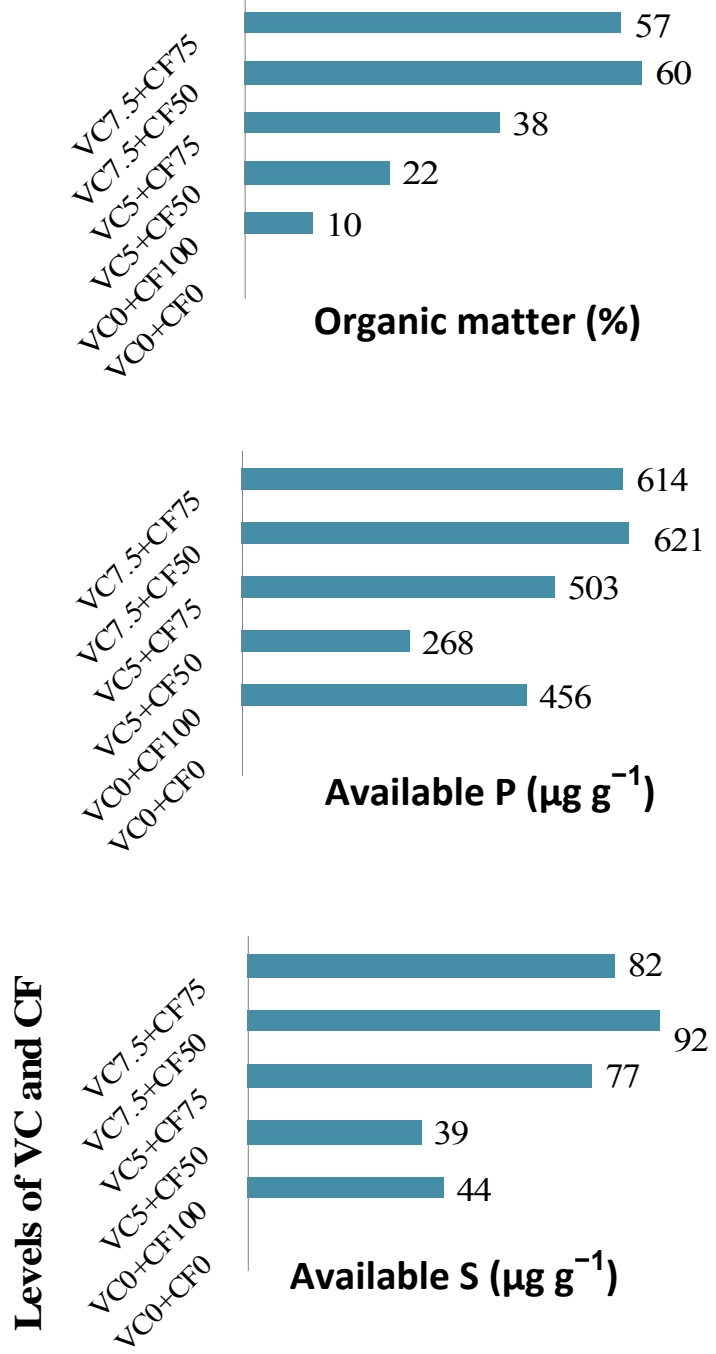

\section{Available $\mathrm{S}\left(\mu \mathrm{g} \mathrm{g}^{-1}\right)$}

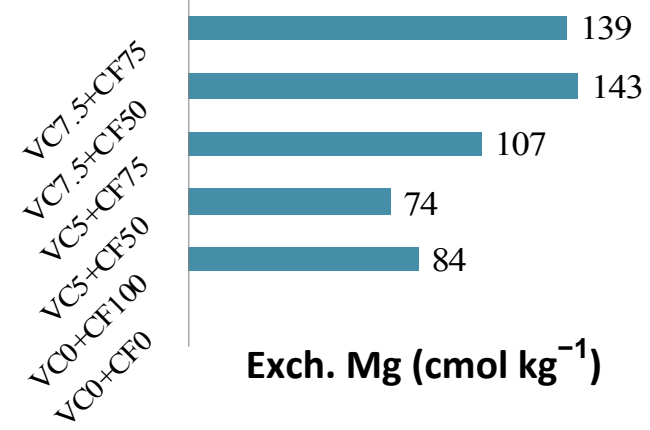

Exch. $\mathrm{Mg}\left(\mathrm{cmol} \mathrm{kg}^{-1}\right)$

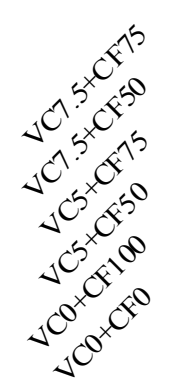

due to the use of vermicompost which indirectly influenced the physical conditions of the soil and supported better aeration to the plant roots and absorption of water.

Different levels of combined application of $\mathrm{VC}$ and $\mathrm{CF}$ significantly increased the soil fertility by increasing different essential elements in soil (Fig. 5). The highest increase percent of nutrients was found from the treatment of $\mathrm{VC}_{7.5}+\mathrm{CF}_{50}$.
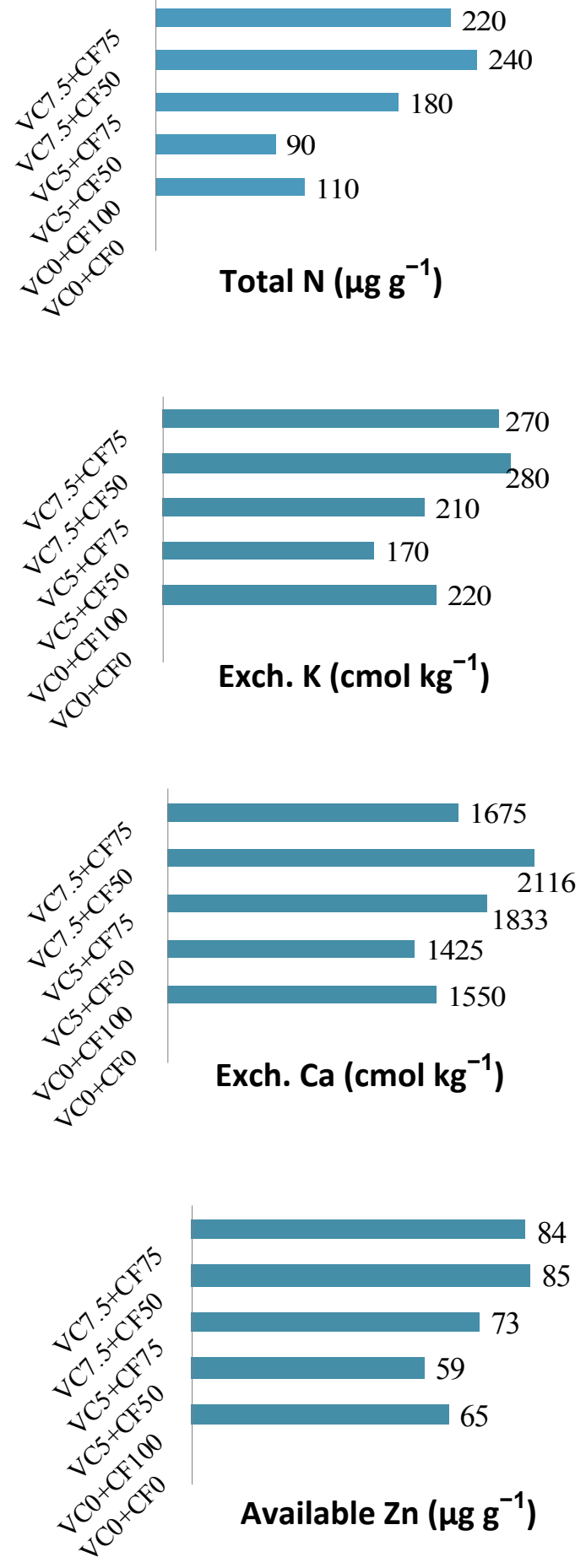

Fig. 5. Integrated effects of vermicompost and chemical fertilizer on percent increase of different nutrients of postharvest soil over control 
Organic fertilizers positively affected soil structure and improved nutrient availability resulting in enhanced yield and quality of crops and were also less costly than synthetic fertilizers (Thy and Buntha 2005; Rekha et al., 2013). Umesha et al. (2011) concluded that organic matters caused better physical, chemical and biological function, which provided carbon as an energy source to soil microbial resulting in enhanced plant growth and yield.

\section{Conclusion}

Results showed that vermicompost along with different rates of chemical fertilizer exerted significant influence on the growth, leaf biomass yield and stevioside content of stevia and postharvest sol fertility. The highest values in most of the parameters were found from the plant receiving VC@ $7.5 \mathrm{t} \mathrm{ha}^{-1}$ along with 50\% CF. About $578 \%$ higher leaf biomass yield was obtained from the treatment $\mathrm{VC}_{7.5}+\mathrm{CF}_{50}$ over control. Stevioside content was increased with increasing the levels of $\mathrm{VC}$ up to 7.5 $\mathrm{t} \mathrm{ha}^{-1}$ along with $75 \% \mathrm{CF}$ and also with the advancement of growth period from 30 to 60 days after planting. The highest amount of stevioside $(11.05 \%)$ was detected in the leaves of the plant that received VC@ $7.5 \mathrm{t} \mathrm{ha}^{-1}$ along with $50 \% \mathrm{CF}$ at harvest. Soil acidity significantly decreased with the increased levels of VC. Total N, available $\mathrm{P}$, exchangeable $\mathrm{K}, \mathrm{Ca}$ and $\mathrm{Mg}$, available $\mathrm{S}, \mathrm{Zn}$ and $B$ were also significantly increased with the increased levels of $\mathrm{VC}$ and $\mathrm{CF}$ up to $50 \%$. The results suggest that the application of vermicompost in combination with chemical fertilizers could be a superior recommendation for greater leaf biomass yield, stevioside content and nutrient uptake by stevia as well as maintaining soil health over the sole use of chemical fertilizers.

\section{Acknowledgement}

The authors wish to express their warm thanks and gratitude to the concerned authority of Bangladesh Agricultural Research Council (BARC), Farmgate, Dhaka for providing fund to conduct this research.

\section{References}

Andolfi, L., Macchia, M. and Ceccarini L. 2006. Agronomicproductive characteristics of two genotype of Stevia rebaudiana in central Italy. Ital. J. Agron., 2: 257-262.

Atarzadeh, S.H., Mojaddam, M. and Nejad, T.S. 2013. The interactive effects humic acid application and several of nitrogen fertilizer on remobilization star wheat. Int. J. Biosci., 3(8): 116-123.

Atiyeh, R.M., Lee, S., Edwards, C.A., Arancon, N.Q. and Metzger, J.D. 2002. The influence of humic acids derived from earthworm-processed organic wastes on plant growth. Bioresour. Technol., 84: 7-14.

Ayyobi, H., Peyvast, G.A. and Olfati, J.A. 2013. Effect of vermicompost and vermicompost extract on oil yield and quality of peppermint (Mentha piperita L.). J. Agr. Sci., 58(1): 51-60

Azarpour, E., Moraditochaee, M. and Bozorgi, H.R. 2013. Effects of vermicompost application under methanol foliar spraying on dry leaf yield and biomass yield of Stevia rebaudiana (Bert.) in north of Iran. ARPN J. Agri. Bio. Sci., 8(5): 419422.
Bachman, G.R. and Metzger, J.D. 2008. Growth of bedding plants in commercial potting substrate amended with vermicompost. Bioresource Technol., 99: 3155-3161.

Das, K. and Dang, R. 2010. Influence of biofertilizers on stevioside content in Stevia rebaudiana grown in acidic soil condition. Arch. Appl. Sci. Res., 2: 44-49.

Dominguez, J., Edwards, C.A. and Subler, S. 1997. A comparison of vermicomposting and composting. Biocycle, 38: 57-59.

Dushyant, S., Maji, S., Kumar, S., Maurya, A.K. and Meena, K.R. 2014. Efficacy of organic manures on growth, yield and biomolecules of stevia (Stevia rebaudiana Bertoni). J. Crop Weed, 10(1): 107-110.

Earanna, N. 2007. Response of Stevia rebaudiana to biofertilizers. Karnataka J. Agric. Sci., 20(3): 616-617.

Fallah, A., Ghalavand, V.M. and Khajepour, R. 2006. Effects of blending method of livestock compost with soil and mixing it with chemical compost on yield and parts of yield of seed corn in Khorramabad, Lorestan. Agric. and Nat. Resour. Sci. Magaz., 40: 233-242.

Farooqi, A.A. and Sreeramu, B.S. 2001. Cultivation of medicinal and aromatic crops, University Press (India) Ltd. Hyderabad, India.

Gill, J.S. and Walia, S.S. 2014. Influence of FYM, brown manuring and nitrogen levels on direct seeded and transplanted rice (Oryza sativa L.) A review. Res. J. Agr. Env. Sci., 3(9): 417-426.

Gomez, K.A. and Gomez, A.A. 1984. Statistical Procedure for Agricultural Research. $2^{\text {nd }}$ eds. International Rice Research Institute. Los Banos, Philippines. pp. 207-215.

Hatti, S.S., Londonkar, R.L., Patil, S.B., Gangawane, A.K. and Patil, C.S. 2010. Effect of Eisenia fetida vermiwash on the growth of plants. J. Crop Sci., 1(1): 6-10.

Jadhav, S.V., Patil, G.M. and Lingappa, S. 2001. Combinations effect of organic and inorganic manures on the quality of M-5 mulberry leaves. Karnataka J. Agril. Sci., 14: 496-499.

Jeyabal, A. and Kuppuswamy, G. 2001. Recycling of organic wastes for the production of vermicompost and its response in ricelegume cropping system and soil fertility. Eur. J. Agron., 15: $153-170$

Joshi, R. and Vig, A.P. 2010. Effect of vermicompost on growth, yield and quality of tomato (Solanum lycopersicum L.). African J. Basic \& Appl. Sci., 2: 117-123.

Kashem, M.A., Sarker, A., Hossain, I. and Islam, M.S. 2015. Comparison of the Effect of Vermicompost and Inorganic Fertilizers on Vegetative Growth and Fruit Production of Tomato (Solanum lycopersicum L.). Open J. Soil Sci., 5: 53-58.

Khanom, S., Saha, B.K., Islam, M.T. and Chowdhury, M.A.H. 2008. Influence of organic and inorganic fertilizers on the growth, leaf yield, chlorophyll and protein contents of stevia grown in different types of soil. Progress. Agric., 19 (1): 23-31.

Khatik, S.K. and Dikshit, P.R. 2001. Integrated use of organic manures and inorganic fertilizers on yield, quality, economics and nutrition of sunflower grown in Haplustert clay soil. Agri. Sci. Digest., 21: 87-90.

Kobayashi, Y., Abe, S. and Matumoto, K. 1989. Growth and yield of paddy rice under natural cultivation. Tohoku Branch Crop Sci. Soc. Japan, 32: 12-13.

Kolb, N., Herrera, J.L., Ferreyra, D.J. and Uliana, R.F. 2001. Analysis of sweet diterpene glycosides from Stevia rebaudiana: Improved HPLC method. J. Agri. Food Chem., 49: 45384541.

Kumar, R., Sharma, S. and Prasad, R. 2013. Yield, nutrient uptake and quality of stevia as affected by organic sources of nutrient. Commun. Soil Sci. Plant. Anal., 44: 3137-3149.

Liu, M., Hu, F., Chen, X., Huang, Q., Jiao, J., Zhang B. and Li, H. 2009. Organic amendments with reduced chemical fertilizer promotes soil microbial development and nutrient availability in a subtropical paddy field: the influence of quantity, type and application time of organic amendments. Appl. Soil Ecol., 42: 166-175.

Liu, X., Ren, G. and Shi, Y. 2011. The effect of organic manure and chemical fertilizer on growth and development of Stevia rebaudiana Bertoni. Energy Procedia, 5: 1200-1204. 
Maheshwar, H.M. 2005. Effect of different levels of nitrogen and dates of planting on growth and yield of stevia (Stevia rebaudiana Bert.). Dept. of Hort., College Agric., Dharwad University Agric. Sci., Dharwad, pp. 55.

Manivannan, S., Balamurugan, M., Parthasarathi, K., Gunasekaran, G. and Ranganat, L.S. 2009. Effect of vermicompost on soil fertility and crop productivity - beans (Phaseolus vulgaris). J. Env. Bio., 30(2): 275-281.

Page, A.L., Miller, R.H. and Keeney, D.R. (eds.). 1982. Method of Soil Analysis, Part-2 Chemical and Microbiological Properties, $2^{\text {nd }}$ edn., American Society of Agronomy, Inc. Madison, Wisconsin, USA.

Parthasarathi, K., Balamurugan, M. and Ranganathan, L.S. 2008. Influence of vermicompost on the physic-chemical and biological properties in different types of soil along with yield and quality of the pulse crop-black gram. Iranian $J$. Environ. Health Sci. Eng., 5(1): 51-58.

Patil, N.M. 2010. Biofertilizer effect on growth, protein and carbohydrate content in Stevia rebaudiana var Bertoni. Recent Res. Sci. Technol., 2(10): 42-44.

Ramya, M., Manogaran, S., Joey, K., Keong, T.W. and Katherasan, S. 2014. Studies on biochemical and medicinal properties of Stevia rebaudiana grown in vitro. Int. J. Ayurveda. Pharm., 5(2): 169-174.

Ramasamy, P.K and Suresh, S.N. 2011. Effect of vermicompost on root numbers and length of sunflower plant (Helianthus annuus L.). J. Pure Applied Microbio., 4(1): 297-302.

Rekha, G.S., Valivittan, K., and Kaleena, P.K. 2013. Studies on the influence of vermicompost and vermiwash on the growth and productivity of black gram (Vigna mungo). Adv. Biol. Res., 7(4): 114-121.

SailajaKumari, M.S. and UshaKumari, K. 2000. Effect of vermicompost enriched with rock phosohate on growth and yield of cowpea (Vigna unguiculata L. Walp). J. Ind. Soc. Soil Sci., 50: 223-224.

Satyanarayana, V., Murthy, V.R.K., Vara Prasad, P.V. and Boote K.J. 2002. Influence of integrated use of farmyard manure and inorganic fertilizers on yield and yield components of irrigated lowland rice. J. Plant Nutr., 25(10): 2081-2090.

Singh, R., Gupta, R.K., Patil, R.T., Sharma, R.R., Asrey, R., Kumar, A. and Jangra, K.K. 2010. Sequential foliar application of vermicompost leachates improves marketable fruit yield and quality of strawberry (Fragaria ananassa Duch.). Sci. Hortic., 124(1): 34-39.

Singh, S., Garg, V., Yadav, D., Nadeem, Beg, M. and Sharma, N. 2012. In vitro antioxidative and antimicrobial activities of various parts of Stevia rebaudiana (Bertoni). Int. J. Pharm. Pharm. Sci., 4(3): 468-473.

Singh, M. and Wasnik, K. 2013. Effect of vermicompost and chemical fertilizer on growth, herb, oil yield, nutrient uptake, soil fertility, and oil quality of rosemary. Commun. Soil. Sci. Plant. Anal., 44(18): 2691-2700.

Steel, R.G.D., Torrie, J.H. and Dickey, D. 1997. Principles and Procedures of Statistics: A biometrical approach. $3^{\text {rd }}$ eds. McGraw Hill Book Co. Inc., New York, USA. pp. 400428.
Taleie, N., Hamidoghli, Y., Rabiei, B. and Hamidoghli, S. 2012. Effects of plant density and transplanting date on herbage, stevioside, phenol and flavonoid yield of Stevia rebaudiana Bertoni. Intl. J. Agra. Crop Sci., 4(6): 298-302.

Tandon, H.L.S. (eds). 1995. Methods of Analysis of Soils, Plants, Waters and Fertilizers. Fertilizer Development and Consultation Organization, New Delhi, India.

Tomati, U., Galli, E., Grappelli, A. and Di Lena, G. 1990. Effect of Earthworm Casts on Protein Synthesis in Radish (Raphanus sativum) and lettuce (Lactuca sativa) seedlings. Biol. Fertil. Soils., 9: 288-289.

Umesha, K., Smitha, G.R., Sreeramu, B.S. and Waman, A.A. 2011. Organic manures and biofertilizers effectively improve yield and quality of stevia (Stevia rebaudiana). J. Appl. Hort., 13(2):157-62.

Vasanthi, D. and Kumarasamy, K. 1996. Efficacy of vermicompost on the yield of rice and on soil fertility. In: National Seminar on Organic Farming and Sustainable Agriculture, Bangalore.

Zaman, M.M., Chowdhury, M.A.H. and Chowdhury, T. 2015a. Growth parameters and leaf biomass yield of stevia (Stevia rebaudiana, Bertoni) as influenced by different soil types of Bangladesh. J. Bangladesh Agril. Univ., 13(1): 31-37.

Zaman, M.M., Chowdhury, M.A.H., Islam, M.R. and Uddin, M.R. 2015b. Effects of vermicompost on growth and leaf biomass yield of stevia and post-harvest fertility status of soil. J. Bangladesh Agril. Univ., 13(2): 169-174.

Zaman, M.M., Chowdhury, M.A.H. and Chowdhury, T. 2015c. Integrated effects of poultry manure and chemical fertilizer on the growth, leaf yield and stevioside content of stevia. $J$. Bangladesh Agril. Univ., 13(2): 175-182.

Zaman, M.M., Chowdhury, M.A.H., Mohiuddin, K.M. and Chowdhury, T. 2016a. Nitrogen requirement and critical N content of stevia grown in two contrasting soils of Bangladesh. Res. Agric. Livest. Fish., 3 (1): 87-97.

Zaman, M.M., Chowdhury, M.A.H., Chowdhury, T. and Hasan, A.B.M.M. 2016b. Critical leaf $\mathrm{S}$ concentration and $\mathrm{S}$ requirement of stevia grown in two different soils of Bangladesh. Fund. Appl. Agric., 1(3): 106-111.

Zaman, M.M., Chowdhury, T., Rahman, M.A. and Chowdhury, M.A.H. 2017a. Phosphorus use efficiency and critical P content of stevia grown in acid and non-calcareous soils of Bangladesh. Res. Agric. Livest. Fish., 4 (2): 55-68.

Zaman, M.M., Chowdhury, T., Rahman, M.A. and Chowdhury, M.A.H. 2017b. Potassium requirement for leaf biomass yield and K nutrition of stevia. Fund. Appl. Agric., 1(3): $106-111$.

Zaman, M.M., Chowdhury, T., Nahar, K. and Chowdhury, M.A.H. 2017c. Effect of cow dung as organic manure on the growth, leaf biomass yield of Stevia rebaudiana and postharvest soil fertility. J. Bangladesh Agril. Univ., 15(2): 206-211.

Zaman, M.M., Nahar, K., Chowdhury, T. and Chowdhury, M.A.H. 2017d. Growth, leaf biomass yield of stevia and postharvest soil fertility as influenced by different levels of poultry manure. J. Bangladesh Agril. Univ., 15(2): 212-218. 